\title{
Prevalence of female genital tract tuberculosis in suspected cases attending Gynecology OPD at tertiary centre by various diagnostic methods and comparative analysis
}

\author{
Diksha Sharma', Anju Depan, Kanti Yadav, Suchitra Narayan ${ }^{1 *}$, Anubhav Sharma ${ }^{2}$
}

\author{
${ }^{1}$ Department of Obstetrics and Gynecology, JLN Medical College Ajmer, Rajasthan, India \\ ${ }^{2}$ Department of T.B. and Chest, J.L.N. Medical College Ajmer, Rajasthan
}

Received: 15 April 2019

Accepted: 30 April 2019

\section{*Correspondence:}

Dr. Suchitra Narayan,

E-mail: narayan_jaiprakash@yahoo.co.in

Copyright: () the author(s), publisher and licensee Medip Academy. This is an open-access article distributed under the terms of the Creative Commons Attribution Non-Commercial License, which permits unrestricted non-commercial use, distribution, and reproduction in any medium, provided the original work is properly cited.

\begin{abstract}
Background: The genital tract tuberculosis is one of the most common causes of tubal factor infertility. This study was conducted to compare the results of different diagnostic methods used in screening for female genital tuberculosis in suspected cases attending Gynecology OPD at RMC, Ajmer.

Methods: This prospective study was conducted in department of obstetrics and gynecology, J. L. N. Medical College, Ajmer, Rajasthan, for studying incidence of genital tuberculosis by various diagnostic methods (viz. AFB smear examination, AFB Lowenstein Jensen culture method, TB-PCR and CBNAAT).

Results: Prevalence of genital TB was 5.5\% in study population of 200 selected women meting the inclusion criteria. $72 \%$ women were in between 20-30 years age group. Oligomenorrhoea (24\%) was found to be significant symptom with $\mathrm{P}$ value of $<0.05$. TBPCR and CBNAAT were found to be statistically significant with $\mathrm{P}$ value of $<0.001$ for diagnosing FGTTB.

Conclusions: We concluded that genital tuberculosis is paucibacillary disease, TBPCR and CBNAAT appears to be rapid and sensitive diagnostic modality.
\end{abstract}

Keywords: AFB, CBNAAT, Culture, FGTTB, Genital tuberculosis, TBPCR

\section{INTRODUCTION}

Tuberculosis (TB) is one of the oldest diseases as old as human civilization. ${ }^{1}$ It is a chronic infectious disease and the morbidity associated with this condition has major health implications. In 1744, the first reported case of female genital tuberculosis was described by Morgagni an anatomist. By polymerase chain reaction (PCR) analysis mycobacterial DNA has been detected in the genital areas of Andean Mummies date from A.D. 140$1200 .^{2}$ The manifestations of tuberculosis in gynaecology were published as a monograph by Hagar in $1886 .^{3}$
Studies have shown that genital infection is seen in 12$24 \%$ of cases with pulmonary tuberculosis. ${ }^{4}$

The genital tract tuberculosis is one of the most common causes of tubal factor infertility. Female genital tuberculosis (FGTB) is an important cause of significant morbidity, short- and long-term sequelae especially infertility whose incidence varies from 3 to $16 \%$ cases in India. Mycobacterium tuberculosis is the etiological agent for tuberculosis. The fallopian tubes are involved in $90-100 \%$ cases, endometrium is involved in $50-80 \%$ cases, ovaries are involved in $20-30 \%$ cases, and cervix is involved in 5-15\% cases of genital TB. 
Tuberculosis of vagina and vulva is rare (1-2\%). The diagnosis is made by detection of acid- fast bacilli on microscopy or culture on endometrial biopsy or on histopathological detection of epithelioid granuloma on biopsy. Polymerase chain reaction may be false positive and alone is not sufficient to make the diagnosis. Laparoscopy and hysteroscopy can diagnose genital tuberculosis by various findings.

The incidence of FGTB is $1-19 \%$ in various parts of India. In infertility patients, incidence of FGTB varies from 3 to $16 \%$ in India with higher incidence being from apex institutes like All India Institute of Medical Sciences (AIIMS), New Delhi, where prevalence of FGTB in women of infertility was $26 \%$ and incidence of infertility in FGTB to be $42.5 \%$, which may be due to referral of difficult and intractable cases to this apex hospital from all over India, especially from states like Bihar where prevalence of TB is very high. ${ }^{5}$

\section{METHODS}

This prospective study was conducted at the department of obstetrics and Gynaecology, J. L. N. (Jawahar Lal Nehru) Medical College, Ajmer, Rajasthan from October 2017 to September 2018, in 200 selected women attending gynaecology OPD at RMC (Rajkiya Mahila Chikitsalaya) AJMER for studying incidence of genital tuberculosis by various diagnostic methods and to compare results of these non invasive methods viz. AFB smear examination, conventional AFB Lowenstein Jensen culture method, TB-PCR and CBNAAT (Cartridge based nucleic acid amplification test) for diagnosing female genital tuberculosis.

The study was presented to Institutional Ethical Committee (IEC) for ethical clearance, after getting clearance form IEC the study was started. The data were collected from the women using a semi structured questionnaire. The socio-demographic factors will be taken by direct interview. After enrollment, detailed history was obtained regarding demographic details, gynecological symptoms, and past history of TB. Details of previous investigations and treatment were noted to rule out other causes of infertility. Explanation of procedure to all women participating in study was done. Consent from every women participating in this study was taken. After physical and gynecological examination all subjects underwent the following investigations:

Blood tests: CBC (Complete Blood Count)/ PBF (peripheral blood Film)/ ESR (Erythrocyte Sedimentation Rate)

- Mantoux (Tuberculn) test (poor sensitivity and specificity)

- $\quad$ Chest X-ray- PA view

- USG - PELVIS and TVS (Transvaginal sonography)

- $\quad$ HIV I AND II tests and VDRL
- Endometrial biopsy, curettage or aspiratePremenstrual Endometrium sample was taken (with help of pipelle's sampling curette) for CBNAAT, AFB smear, AFB Culture

- Histopathology examination (HPE) (demonstration of epitheloid granuloma)

- Mycobacterial AFB smear and culture using Lowenstien- Jensen (LJ) medium

- Molecular methods (CBNAAT/ TBPCR)-

a. TBPCR (Polymerase Chain Reaction) - For TBPCR premenstrual endometrial biopsy sample taken in Normal Saline and was sent . PCR test was carried out using IS6110 and TRC4 probes. The test involved processing of samples, amplification and isolation of DNA. Demerit of TBPCR is that it's costly it was done only in affordable and feasible women.

b. CBNAAT9 (Cartridge Based Nucleic Acid Amplification Test/ Gene Xpert)- For CBNAAT (Cartridge Based Nucleic Acid Amplification Test/ Gene Xpert)

- Diagnostic laparoscopy: Laparoscopy criteria were grouped as either suggestive (type 1 or abnormal) or non-suggestive (type 2 normal) of GTB.

\section{Inclusion criteria}

The 200 selected suspected cases were of viz

- Menstrual irregularities- oligomenorrhoea, hypomenorrhoea, amenorrhoea, menorrhagia, dysmenorrhoea, metrorrhagia. After ruling out of other causes by routine investigations, usg and various serum hormonal assays viz. S.TSH/ S.prolactin/ FSH/ LH/ DHEA

- Infertility - unexplained infertility. Women in whom infertility was due male factors, ovulation disorders, endometriosis, sexual dysfunction were excluded from study

- Chronic pelvic pain

- Chronic pelvic inflammatory disease resistant to standard antibiotic treatment according to CDC 2015 guideline for PID. ${ }^{6-8}$

\section{Exclusion criteria}

- Immuno compromised (HIV)women

- Women suffering from other known granulomatous diseases like chron's diseases, leprosy, filariasis, silicosis

- Patient already treated for TB or extra pulmonary TB

- Known or suspected malignancy

- Acute PID

- Women on steroid treatment

- Menstrual irregularities due to hormonal irregularities. 
Women who were positive for mycobacterium tuberculosis by AFB smear, AFB culture, CBNAAT and TBPCR were treated with standard anti tuberculosis treatment (ATT) in category 1 under RNTCP and were followed up.

\section{Statistical analysis}

The data was coded and entered into Microsoft Excel spreadsheet. Analysis was done using SPSS version 20 (IBM SPSS Statistics Inc., Chicago, Illinois, USA) Windows software program. Descriptive statistics included computation of percentages, means and standard deviations. Chi-square test used for qualitative data whenever two or more than two groups were used to compare. Level of significance was set at $\mathrm{P} \leq 0.05$.

\section{RESULTS}

In present study the mean age in this study was $27.91 \pm 5.88$ years and maximum $144(72 \%)$ women in between 20-30 years age group, while $52(26 \%)$ were in age group 30-40 years (Table 1). 74 (37\%) were having normal menstrual cycle, Oligomenorrhoea was found to be statistically significant symptom in women with genital tuberculosis with $\mathrm{P}$ value of $<0.05$.

$68(34 \%)$ women complained of white discharge per vagina resistant to treatment given according to $\mathrm{CDC}$ guidelines for $>6$ months and $132(66 \%)$ women were not having discharge per-vaginal. $78.5 \%$ (157) women presented with complaint of infertility. $141 \quad(89.8 \%)$ women out of 157 were of primary infertility and 16 $(10.2 \%)$ were of secondary infertility.

Table 1: Distribution according to menstrual irregularities.

\begin{tabular}{|llllll|}
\hline \multirow{2}{*}{$\begin{array}{l}\text { Menstrual irregularity } \\
\text { Normal cycle }\end{array}$} & Case No. & Culture & CBNAAT & TBPCR & P value \\
\hline Oligomenorrhoea & $74(37 \%)$ & 1 & 2 & 2 & $>0.05$ \\
\hline Menorrhagia & $48(24 \%)$ & 3 & 7 & 2 & $<0.05(\mathrm{~S})$ \\
\hline Dysmenorrhoea & $26(13 \%)$ & 0 & 0 & 0 & $>0.05$ \\
\hline Hypomenorrhoea & $27(13.5 \%)$ & 0 & 0 & 0 & $>0.05$ \\
\hline Total & $25(12.5 \%)$ & 0 & 1 & 0 & $>0.05$ \\
\hline P value & 200 & 4 & 10 & 4 & $>0.05$ \\
\hline
\end{tabular}

Test applied chi square test

Table 2: Relationship between diagnostic laparoscopy findings, FGTTB, AFB culture, TB-PCR and CBNAAT.

\begin{tabular}{|c|c|c|c|c|}
\hline \multirow{2}{*}{$\begin{array}{l}\text { Diagnostic laparoscopy } \\
\text { findings }\end{array}$} & Total no of cases & AFB Culture & CBNAAT & TBPCR \\
\hline & \multicolumn{4}{|c|}{ FGTTB } \\
\hline Abnormal & $27(39.7 \%)$ & 2 & 6 & 4 \\
\hline Normal & $41(60.3 \%)$ & 0 & 0 & 0 \\
\hline Total & 68 & 2 & 6 & 4 \\
\hline$P$ value & & 0.08 & $0.001(\mathrm{~S})$ & $0.001(\mathrm{~S})$ \\
\hline
\end{tabular}

Test applied Chi Square test

A total of 68 women went under diagnostic laparoscopy, out of them $41(60.3 \%)$ were having normal findings and bilateral dye spillage was seen and 27 (39.7\%) women were having abnormal findings suggestive of genital tuberculosis viz. Delayed dye spillage $6 \quad(8.8 \%)$, hydrosalpinx present $7(10.3 \%)$, beaded appearance of fallopian tubes $5(7.3 \%)$, granulomas $1(1.4 \%)$, pelvic congestion 1 (1.4\%), pelvic adhesions 5 (7.3\%) and bilateral dye spillage absent $15(22 \%)$ and unilateral dye spillage seen $10(14.7 \%)$. In $27(39.7 \%)$ women with abnormal findings 2 were found positive for FGTTB by AFB culture, 6 found positive by CBNAAT and 4 found positive for FGTTB by TBPCR as shown in Table 2 and 3.
In TST test 77 (37.5\%) women were found reactive and $123(62.5 \%)$ were found non reactive. $162(81 \%)$ women were having normal ESR and 38 (19\%) were having increased ESR. Out of 38, 9 women were found positive for FGTTB by CBNAAT and 3 were found by TBPCR and 4 were found positive by AFB culture. Sensitivity of CBNAAT test was found to be $75 \%$, specificity $96.42 \%$, positivity rate of $5 \%$, positive predictive value of $30 \%$ and negative predictive value of $99.42 \%$ and results were highly significant with $\mathrm{P}$ value of $<0.001$. Sensitivity of TBPCR test was found to be $50 \%$, specificity of $100 \%$, positivity rate of $2.78 \%$, with a $\mathrm{P}$ value of $<0.001$. As PCR is a costly investigation, only 144 women underwent TBPCR. In present study prevalence of FGTB 
was found to be $5.5 \%$ when all mentioned tests were included.

Table 3: Diagnostic laparoscopy findings in infertility women suspected for FGTTB.

\begin{tabular}{|ll|}
\hline $\begin{array}{l}\text { Diagnostic laparoscopy findings } \\
\text { in women suspected for FGTTB }\end{array}$ & $\begin{array}{l}\text { Total no. of cases } \\
\mathrm{n}=68\end{array}$ \\
\hline $\begin{array}{l}\text { Bilateral dye spillage seen } \\
\text { (normal findings) }\end{array}$ & $41(60.3 \%)$ \\
\hline Bilateral Dye spillage absent & $15(22 \%)$ \\
\hline Delayed dye spillage & $6(8.8 \%)$ \\
\hline Hydrosalpinx present & $7(10.3 \%)$ \\
\hline Beaded appearance & $5(7.3 \%)$ \\
\hline Granulations & $1(1.4 \%)$ \\
\hline Adhesions & $5(7.3 \%)$ \\
\hline Unilateral dye spillage & $10(14.7 \%)$ \\
\hline Pelvic congestion & $1(1.4 \%)$ \\
\hline
\end{tabular}

\section{DISCUSSION}

In Present study we found the prevalence of genital TB $5.5 \%$ (provided all investigations used in study are included) in study population of 200 selected women meting the inclusion criteria. However, prevalence of
FGTTB were found by Shaheen et al, Pakistan, Nadgouda et al, India, Khanna and Agarwal, India, Abdelrub et al, Yemen, Pratibha et al, India, Thangappah et al, India $2.43 \%, 10 \%, 26 \%, 6.9 \%, 9.3 \%$ and $39 \%$ respectively as shown in Table $4 .{ }^{11-16}$ In this study the mean age was $27.91 \pm 5.88$ years and maximum 144 (72\%) women in between 20-30 years age group however in Thanagappah et al16 2018 reported in their study mean age of presentation was 27.35 years and Arpitha VJ et al, reported mean age of patients were $28.89 \pm 4.23$ years. ${ }^{14}$ Oligomenorrhoea was found to be statistically significant symptom however, Radha BP Thangappah et al in reported menstrual disturbances such as secondary amenorrhoea, oligomenorrhoea, and menorrhagia were seen in $27.7 \%$ women and Arpitha VJ et al in reported that majority of women had a normal menstrual cycle $76.8 \%$ and hypomenorrhoea was the most common menstrual abnormality in $8.7 \%$ women followed by oligomenorrhoeaI $(5.8 \%){ }^{14,16} 68 \quad(34 \%)$ women complained of white discharge per vagina resistant to treatment however, Thangappah et al reported that vaginal discharge not responding to treatment for more than two years was seen in $5(3 \%)$ cases out of 161 and Jindal UN et al reported that $6(3 \%)$ patients out of 197 patients presented with white vaginal discharge. ${ }^{16,17}$

Table 4: Studies on the prevalence of genital tuberculosis reported in literature.

\begin{tabular}{|c|c|c|c|}
\hline Author, country (year) & Study design & Number of participants & Prevalence of genital TB (\%) \\
\hline Tripathy and Tripathy, India ${ }^{4}$ & Prospective & 91 & $\begin{array}{l}3 \% \text { (overall) } 41 \text { (in cases with tubal } \\
\text { infertility) }\end{array}$ \\
\hline Jindal, India $^{17}$ & Retrospective & 150 & $48 \%$ \\
\hline Shaheen et al, Pakistan ${ }^{11}$ & Prospective & 534 & $2.43 \%$ \\
\hline Singh et al, India ${ }^{10}$ & Retrospective & 140 & $48.5 \%$ (in cases with tubal infertility) \\
\hline Nadgouda et al, India ${ }^{12}$ & Prospective & 170 & $5.8 \%$ \\
\hline Khanna and agarwal, India ${ }^{13}$ & Cross sectional & 100 & $26 \%$ \\
\hline Abdelrub et al, Yemen ${ }^{14}$ & Prospective & 682 & $\begin{array}{l}6.9 \% \text { (overall) } 31 \text { (in cases with tubal } \\
\text { infertility) }\end{array}$ \\
\hline Pratibha et al, India ${ }^{15}$ & Prospective & 160 & $9.3 \%$ \\
\hline Thangappah et al, India ${ }^{16}$ & Prospective & 153 & $25.4 \%$ \\
\hline Present study, India & Prospective & 200 & $5.5 \%$ \\
\hline
\end{tabular}

There were $77(37.5 \%)$ Women were found reactive by TST Test however, Thangappah et al in reported that a positive TST test or Mantoux test with an induration of $>10 \mathrm{~mm}$ was seen in $37(21.4 \%)$ cases out 161 total cases and In 29 of the 37 cases with positive tuberculin test, other diagnostic parameters were also positive. ${ }^{16}$ Therefore, TST test has been included as one of the diagnostic criteria to suspect Genital tuberculosis. Thangappah et al, in 2018 reported that 27 patients (15.6\%) out 161 patients total were having abnormal ESR on investigating. ${ }^{16}$ Among the 27 cases with elevated
ESR, in 21 of them other diagnostic parameters were also positive. Thangappah et al, reported that 93 (53.8\%) women were having normal findings on laparoscopy and $20(11.6 \%)$ women were having definite evidence of TB findings such as granulomas, caseation, calcification and tubercles, in another $18(10.4 \%)$ cases there was probable evidence of tuberculosis with hydrosalpinx dilated retort shaped tubes, tubes covered with white plaques and exudates, dense adhesions and loculated ascities and in remaining 42, there was suspicion of tuberculosis because of minimal adhesions, and cornual block. ${ }^{16}$ 
Table 5: Comparative parameters of present study with previous studies.

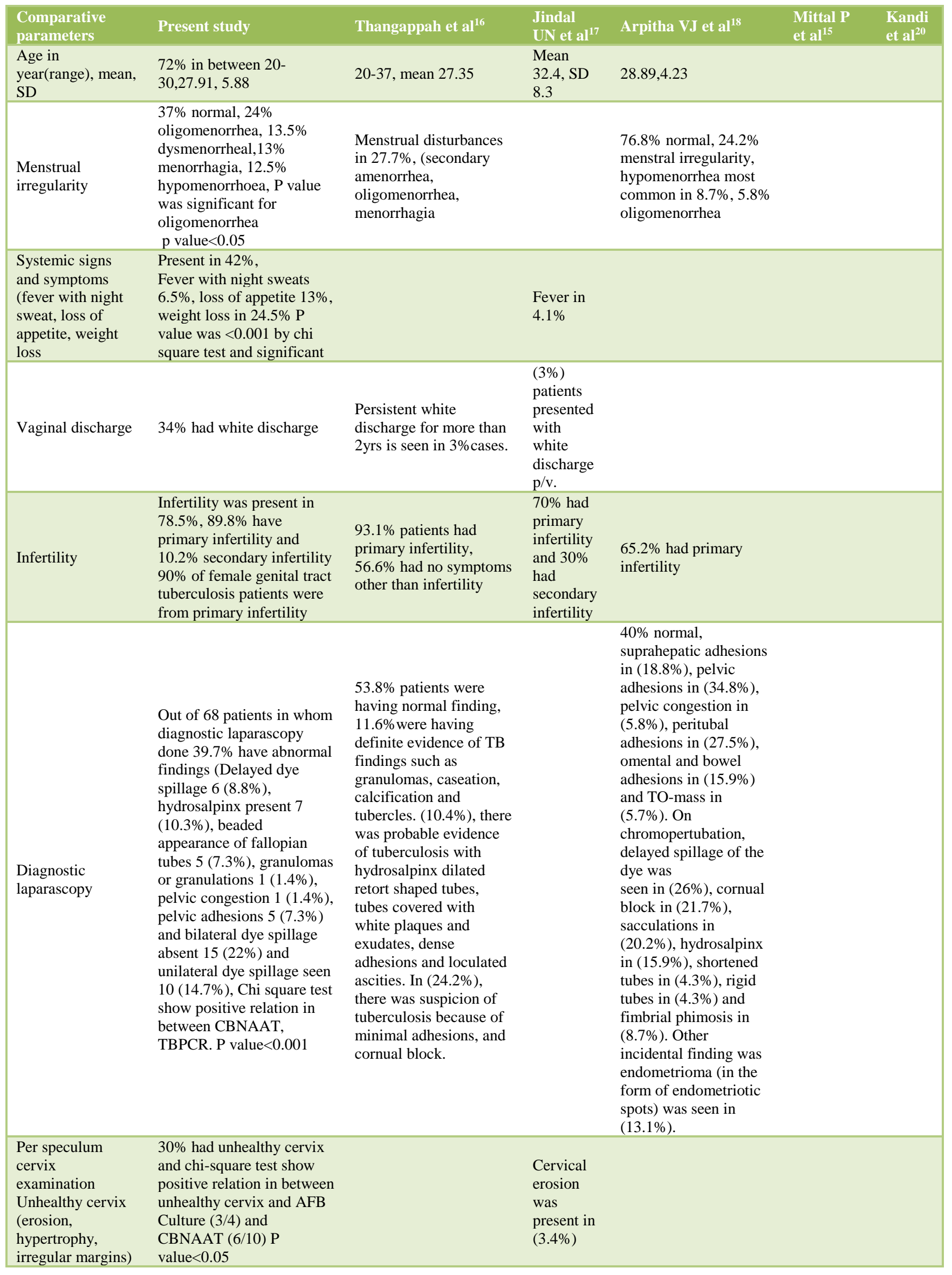




\begin{tabular}{|c|c|c|c|c|c|c|}
\hline $\begin{array}{l}\text { Comparative } \\
\text { parameters }\end{array}$ & Present study & $\begin{array}{l}\text { Thangappah et } \\
\text { al }^{16}\end{array}$ & $\begin{array}{l}\text { Jindal UN et } \\
\text { al }^{17}\end{array}$ & $\begin{array}{l}\text { Arpitha VJ et } \\
\mathrm{al}^{18}\end{array}$ & $\begin{array}{l}\text { Mittal P } \\
\text { et } \text { al }^{15}\end{array}$ & $\begin{array}{l}\text { Kandi } \\
\text { et } \mathbf{a l}^{20}\end{array}$ \\
\hline $\begin{array}{l}\text { Fornix/adnexal } \\
\text { tenderness }\end{array}$ & $\begin{array}{l}\text { Fornix tenderness } \\
\text { present in } 8 \% \text { patients } \\
\text { and AFB culture, } \\
\text { CBNAAT, and TBPCR } \\
\text { were positive in } 1,3,2 \\
\text { patients and chi square } \\
\text { test show P value }<0.05 \\
\text { for CBNAAT and } \\
\text { TBPCR. }\end{array}$ & & $\begin{array}{l}\text { Reported } \\
\text { (5.04\%) patients } \\
\text { presented with } \\
\text { adenexal } \\
\text { fornicial } \\
\text { tenderness. }\end{array}$ & & & \\
\hline MT test & $\begin{array}{l}(37.5 \%) \text { patients were } \\
\text { found reactive, AFB } \\
\text { culture, CBNAAT, and } \\
\text { TBPCR were positive in } \\
4,7.2 \text { patients } \\
\text { respectively and chi } \\
\text { square test show } \\
\text { significant p value }<0.05 \\
\text { for CBNAAT and AFB } \\
\text { culture }\end{array}$ & $\begin{array}{l}\text { Reported that a } \\
\text { positive TST test } \\
\text { or Mantoux test } \\
\text { with an induration } \\
\text { of >10mm was } \\
\text { seen in } 37 \\
(21.4 \%) \text { cases. In } \\
29 \text { of the } 37 \text { cases } \\
\text { with positive } \\
\text { tuberculin test, } \\
\text { other diagnostic } \\
\text { parameters were } \\
\text { also positive }\end{array}$ & & & & \\
\hline ESR & $\begin{array}{l}(19 \%) \text { patients } \\
\text { having increased } \\
\text { (Abnormal). } 9 \text { patients } \\
\text { were positive for } \\
\text { CBNAAT, } 3 \text { for } \\
\text { TBPCR, AND } 4 \text { were } \\
\text { for AFB culture and chi } \\
\text { square test was statically } \\
\text { significant p value } \\
<0.001\end{array}$ & $\begin{array}{l}27 \text { patients } \\
(15.6 \%) \text { out } 161 \\
\text { patients total were } \\
\text { having abnormal } \\
\text { ESR on } \\
\text { investigating. } \\
\text { Among the } 27 \\
\text { cases with } \\
\text { elevated ESR, in } \\
21 \text { of them other } \\
\text { diagnostic } \\
\text { parameters were } \\
\text { also positive. }\end{array}$ & & & & \\
\hline $\begin{array}{l}\text { Incidence of } \\
\text { female genital } \\
\text { tract tuberculosis }\end{array}$ & $\begin{array}{l}\text { Out of } 200 \text { total patients } \\
\text { positive for TB was } 11 \text {, } \\
1 \text { positive for smear, } 10 \\
\text { by CBNAAT, } 4 \text { by AFB } \\
\text { culture, and } 4 \text { by } \\
\text { TBPCR with incidence } \\
\text { of } 5.5 \%\end{array}$ & $\begin{array}{l}4.6 \% \text { of the } \\
\text { endometrial } \\
\text { samples were } \\
\text { positive for AFB } \\
\text { smear, } \\
\text { AFB culture was } \\
\text { positive in } 3.5 \% \\
\text { cases. } \\
\text { PCR was positive } \\
\text { in } 28.1 \% \text { of } \\
\text { endometrial } \\
\text { samples. }\end{array}$ & & $\begin{array}{l}69 \text { patients } \\
\text { positive for } \\
\text { endometrial } \\
\text { TBPCR none } \\
\text { of the cases } \\
\text { shown positive } \\
\text { results on TB } \\
\text { BACTEC } \\
\text { (culture) or by } \\
\text { ZN staining. }\end{array}$ & $\begin{array}{lr}\text { Out of } & 160 \\
\text { genital samples, } \\
\text { a total of } & 9.3 \% \\
(15 / 160) & \text { were } \\
\text { positive, } & 53.3 \% \\
(8 / 15) & \text { were } \\
\text { detected } & \text { by } \\
\text { PCR, } & 33.3 \% \\
(5 / 15) & \text { detected } \\
\text { by BACTEC, } \\
33.3 \% & (5 / 15) \\
\text { cases } & \text { detected } \\
\text { by AFB } & \text { culture } \\
\text { and } & 6.66 \% \\
(1 / 15) & \text { cases } \\
\text { detected } & \text { by } \\
\text { direct } & \text { AFB } \\
\text { smear } & \\
\text { examination. }\end{array}$ & $\begin{array}{l}\text { Reported that } \\
\text { for } \\
\text { extrapulmona } \\
\text { ry samples } \\
\text { the sensitivity } \\
\text { and } \\
\text { specificity for } \\
\text { CBNAAT } \\
\text { samples were } \\
85.7 \% \text { and } \\
93.5 \% \text { r } \\
\text { respectively }\end{array}$ \\
\hline
\end{tabular}

Arpitha VJ et al reported that 69 women went under laparoscopy and $40 \%$ had no evidence of genital tuberculosis on laparoscopy and in rest $60 \%$ women on laparoscopy had: suprahepatic adhesions in 13 (18.8\%), pelvic adhesions in $24(34.8 \%)$, pelvic congestion in 4 $(5.8 \%)$, peritubal adhesions in $19(27.5 \%)$, omental and bowel adhesions in $11(15.9 \%)$ and TO-mass in $4(5.7 \%)$, on chromopertubation, delayed spillage of the dye was seen in 18 (26\%), cornual block in $15(21.7 \%)$, sacculations in $13(20.2 \%)$, hydrosalpinx in $11(15.9 \%)$, shortened tubes in $3(4.3 \%)$, rigid tubes in $3(4.3 \%)$ and fimbrial phimosis in $6(8.7 \%)$, Other incidental finding endometrioma in $9(13.1 \%) .{ }^{14}$ In present study prevalence 
of FGTB was found to be $5.5 \%$ when all mentioned tests were included.

Out of 200 samples, a total of $11(5.5 \%)$ were positive, $1 / 11(9.09 \%)$ were detected by direct AFB smear examination, 10/11 (90.9\%) were detected by CBNAAT, 4/11 $(36.36 \%)$ were detected by AFB culture and 4/11 $(36.36 \%)$ were detected by TBPCR. Out of 200 women $144(72 \%)$ women were tested by TBPCR, by TBPCR the incidence of Female genital tuberculosis was $2.78 \%$. Kandi et al, reported that for extra pulmonary samples the sensitivity and specificity for CBNAAT samples were $85.7 \%$ and $93.5 \%$ respectively. ${ }^{20}$ Table 5 shows the comparative parameters of present study with previous studies.

\section{CONCLUSION}

We concluded that genital tuberculosis is paucibacillary disease, TBPCR and CBNAAT appears to be rapid and sensitive diagnostic modality. But both can neither confirm nor exclude genital tuberculosis. But by combining all tests TST test, ESR, Laparoscopy, AFB culture, AFB smear examination, TBPCR and CBNAAT can effectively confirm an early diagnosis of GTB.

\section{Funding: No funding sources}

Conflict of interest: None declared

Ethical approval: The study was approved by the Institutional Ethics Committee

\section{REFERENCES}

1. Rao KN. History of tuberculosis. In: Text book of Tuberculosis - $2^{\text {nd }}$ Edition. Vikas Publishing house; 1981.

2. Konomi N, Lebwohl E, Mowbray K, Tattersall I, Zhang D. Detection of mycobacterial DNA in andean mummies. J Clin Microbiol. 2002;40(12) 4738-40.

3. Broune AW, Williams LM. Genital tuberculosis: in recent advances in Obstetrics/Gynaecology $2^{\text {nd }}$ edition, $10^{\text {th }}$ volume, London; 1962.

4. Tripathy SN. Genital affection in pulmonary tuberculosis. Ind J Th. 1991;38:191.

5. Sharma J. Current diagnosis and management of female genital tuberculosis. J Obstet Gynecol India. 2015;65(6):362-71.

6. Urdea M, Penny LA, Olmsted SS. Requirements for high impact diagnostics in the developing world. Nature. 2006;444:73-9.

7. ACOG Committee on Practice Bulletins. ACOG Practice Bulletin No. 51, Chronic Pelvic Pain. Obstet Gynaecol. 2004;103:589-605.
8. Centers for Disease Control and Prevention Sexually transmitted diseases treatment guidelines. MMWR Recomm Rep. 2015;64(RR-3):11-37.

9. Brission-Noel A, Azner C, Chureau C, Nquyen S, Pierre C, Bartoli M, et al. Diagnosis of tuberculosis by DNA amplification in clinical practice. Lancet. 1991;338:364-6.

10. Singh N, Sumana G, Mittal S. Genital tuberculosis a leading cause for infertility in women seeking assisted conception in North India. L Arch Gynaecol Obstet. 2008;278:325-7.

11. Shaheen R, Subhan F, Tahir F. Epidemiology of genital tuberculosis in infertile population. J Pak Med Assoc. 2006;56:306-9.

12. Nadgouda SS, Mukhopadhyaya PN, Acharya A, Nagee A, Kunjadia PD. A study on genital tuberculosis and infertility in Indian population. Clin Pract. 2010;2:1.

13. Khanna A, Agrawal A. Markers of genital tuberculosis ininfertility. Singapore Med J. 2011;52:864-7.

14. Abdelrub AS, Al Harazi AH, Al-Eryani AA. Genital tuberculosis is common among females with tubal factor infertility: Observational study. Alex J Med. 2015;51:321-4.

15. Mittal P, Gupta S. A Comparative study for detection of mycobacteria by direct AFB smear examination, culture by lowenstein jensen media, fluorescent sensor technology based bactecTM micro MGITTM system \& PCR. IJMSE:pISSN-2348 4438 eISSN2016;3:2349-3208:257-63.

16. Radha BP. Thangappah. diagnosing genital tuberculosis in female infertility by clinical, histopathological, culture and PCR techniques: an evaluative study. Int $\mathbf{J}$ Reprod Contracept Obstet Gynaecol. 2018;7(3):1142-8.

17. Jindal UN. An algorithmic approach to female genital tuberculosis causing infertility. Int J Tuberc Lung Dis. 2006;10(9):1045-50.

18. Arpitha VJ. Diagnosis of genital tuberculosis: correlation between polymerase chain reaction positivity and laparoscopic findings. Int $\mathrm{J}$ Reprod Contracept Obstet Gyanecol. 2016;5(10):3425-32.

19. Rozati R, Roopa S, Rajeswari CN. Evaluation of women with infertility and genital tuberculosis. J Obstet Gynaecol India. 2006;56(5):423-6.

20. Kandi S, Reddy V, Nagaraja SB. Diagnosis of pulmonary and extra pulmonary tuberculosis: How best is CBNAAT when compared to conventional methods of TB detection? Pulm Res Respir Med Open J. 2017;4(2):38-41.

Cite this article as: Sharma D, Depan A, Yadav K, Narayan S, Sharma A. Prevalence of female genital tract tuberculosis in suspected cases attending Gynecology OPD at tertiary centre by various diagnostic methods and comparative analysis. Int $\mathbf{J}$ Reprod Contracept Obstet Gynecol 2019;8:2286-92. 